\title{
Pola Reduplikasi Bahasa Bali: Perbandingannya dengan Pola Reduplikasi Bahasa-bahasa Austronesia
}

\author{
I Gede Bagus Wisnu Bayu Temaja \\ Ilmu Linguistik, Universitas Gadjah Mada, Yogyakarta, Indonesia \\ wisnubt@gmail.com
}

\section{Article Info}

Article history:

Submitted Jan 18, 2018

Revised April 20, 2018;

July 29, 2018

Accepted July 31, 2018

Published November 21, 2018

\section{Keywords:}

Reduplication

Patterns

comparative

\begin{abstract}
This research aimed at explaining the reduplication patterns of Balinese language based on reduplication patterns exist in Austronesian languages. The research was conducted by implementing these three steps consist of: data collection, data analysis, and data display. The data were collected by interview by means of interview-guided, recording, and note-taking techniques. Data analysis was conducted by implementing comparative method in which by comparing between common reduplication patterns in Austronesian languages (Blust, 2013) and Balinese language. The result of analysis were displayed in formal and informal way. Based on the results, 4 reduplication patterns found in Balinese language out of 16 patterns in Austronesian languages, and detailed as follows: (1) full reduplication, (2) full reduplication plus affixation, (3) full reduplication with vocalic or consonantal change, or both, and (4) Ca-reduplication. Furthermore, it was found a new pattern namely Cə-reduplication in Balinese language which was unavailable in Austronesian languages theory yet.
\end{abstract}

\section{Corresponding Author:}

I Gede Bagus Wisnu Bayu Temaja, Ilmu Linguistik, Universitas Gadjah Mada, Yogyakarta, Indonesia Bulaksumur, Caturtunggal, Depok, Sleman, Yogyakarta 55281

Email: wisnubt@gmail.com

\section{PENDAHULUAN}

Bahasa Bali merupakan salah satu bahasa Austronesia yang menjadi bahasa ibu bagi suku Bali yang berdiam di Pulau Bali, Indonesia. Sebagai bahasa yang masuk ke dalam sepuluh besar bahasa daerah dengan penutur terbanyak di Indonesia membuat bahasa ini penting keberadaannya. Bahasa Bali dipergunakan dalam urusan pemerintahan, pendidikan, dan urusan lainnya di samping untuk percakapan sehari-hari. Pada tataran dokumentasi bahasa baik itu tata bahasa maupun pengkamusannya secara komprehensif belum bisa dikatakan rampung sepenuhnya. Untuk melengkapi dokumentasi tersebut maka penelitian ini dilaksanakan. Salah satunya yaitu pada bidang morfologi yang belum dilaksanakan secara keseluruhan. Morfologi yang termasuk ke dalam tata bahasa tersebut merupakan area yang perlu di teliti lebih lanjut. Dalam morfologi, terdapat macam-macam proses morfologis seperti afiksasi, reduplikasi, ataupun komposisi. Proses yang dikaji dalam penelitian ini adalah proses morfologis yang berupa reduplikasi.

Menurut Verhaar (2008:152), reduplikasi adalah proses morfemis yang mengulang bentuk dasar atau sebagian dari bentuk dasar tersebut. Hal cukup senada juga diungkapkan oleh Matthews (1978:127) yang menyatakan bahwa reduplikasi merupakan 
bentuk perulangan yang tidak hanya keseluruhan tetapi dapat pula parsial. Lebih lanjut, Ramlan (1979:65) menjelaskan lebih spesifik menjelaskan perulangan sebagai pengulangan satuan gramatika, baik seluruhnya maupun sebagiannya, baik dengan variasi fonem maupun tidak. Dari ketiga pernyataan tersebut diperoleh kesimpulan bahwa reduplikasi menyangkut perulangan dari bentuk dasar secara menyeluruh maupun sebagian; baik dengan silabel, variasi fonem, dan lainnya. Untuk menganalisis pola reduplikasi suatu bahasa, terutama pada bahasa yang belum pernah dilaksanakan penelitian terkait, bisa dilaksanakan dengan melihat deskripsi sejenis pada penelitian bahasa-bahasa lain dalam satu rumpun, seperti rumpun bahasa Austronesia. Seperti yang diketahui bahwa bahasa Bali merupakan anggota rumpun bahasa Austronesia.

Samsuri (1982:191) berpendapat bahwa reduplikasi sebagai proses morfologis yang banyak sekali ditemukan pada bahasa-bahasa di dunia. Kemudian, pada bahasa-bahasa Austronesia sendiri Blust (2013) menyebutkan bahwa bahasa-bahasa Austronesia sangat begitu dipengaruhi oleh aspek reduplikasi ini, termasuk bahasa Bali. Mengingat sudah didokumentasikannya reduplikasi bahasa-bahasa Austronesia oleh para peneliti seperti Blust, sehingga ini bisa dijadikan acuan untuk mendeskripsikan reduplikasi dalam bahasa Bali dan melihat bagaimana proses morfologis ini diwariskan. Berdasarkan pemaparan tersebut, adapun rumusan masalah dari penelitian ini, yaitu: 1) Apa sajakah pola reduplikasi yang ada pada bahasa Bali berdasarkan perbandingannya dengan pola reduplikasi yang ada pada bahasa-bahasa Austronesia? Berdasarkan rumusan masalah tersebut dapat ditarik tujuan penelitian ini yaitu untuk: 1) Menguraikan pola reduplikasi yang ada pada bahasa Bali berdasarkan pola-pola reduplikasi yang ada pada bahasabahasa Austronesia secara umum.

Kajian tentang pola reduplikasi bahasa Bali belum banyak dilakukan. Salah satunya penelitian yang sudah dibukukan dari Bawa dan Jendra (1981) berjudul 'Struktur Bahasa Bali'. Dalam penelitian tersebut ditemukan tiga pola reduplikasi bahasa Bali, yaitu reduplikasi utuh, reduplikasi utuh dengan variasi vokal, dan reduplikasi parsial, serta kombinasinya dengan afiks (prefiks, konfiks, dan sufiks). Tetapi, penelitian tersebut hanya melihat secara deskriptif pola reduplikasinya tanpa membandingkannya dengan dengan pola reduplikasi yang ada pada bahasa-bahasa Autronesia secara umum. Sedangkan penelitian reduplikasi pada bahasa lain serumpun juga sudah dilaksanakan, seperti dari Hilsam (2016) dengan judul "Reduplikasi Bahasa Tolaki" dan Due (2016) berjudul "Reduplikasi Bahasa Kambowa". Kedua penelitian tersebut menginvestigasi sistem reduplikasi secara deskriptif dengan melihat bentuk, fungsi, dan maknanya. Pada kedua bahasa ditemukan bentuk reduplikasi utuh, reduplikasi sebagian, dan reduplikasi berafiks dari lima kategori, seperti nomina, verba, numeralia, adjektiva, dan pronomina. Fungsi yang dibahas yaitu fungsi gramatikal dan fungsi morfologis. Pada bahasa Tolaki, makna yang ditemukan pada sistem reduplikasinya yaitu makna yang 'menyatakan kecil', 'lebih dari satu', 'makna sangat' yang bergantung pada afiks pembentuknya, 'makna agak', 'makna berbagai', dan 'makna seruan'. Sedangkan, makna pada reduplikasi bahasa Kambowa menyatakan 'makna banyak', 'makna santai', 'makna jumlah', 'makna semua', 'makna menyerupai', 'makna berbagai', dan 'makna agak. Lebih lanjut, Rizal (2016) melaksanakan penelitian yang berjudul "Sistem Reduplikasi Bahasa Muna (Suatu Kajian Transformasi Generatif)". Dalam penelitiannya tersebut ditemukan bahwa reduplikasi pada bahasa tersebut terbagi atas reduplikasi utuh, reduplikasi sebagian, dan reduplikasi berafiks. Berdasarkan beberapa penelitian tersebut, penelitian ini mencoba untuk mendeskripsikan secara berbeda reduplikasi bahasa Bali. Berkaca dari tinjauan pustaka di atas, penelitian reduplikasi pada bahasa sebuah bahasa dengan membandingkannya dengan bahasa-bahasa Austronesia belum mendapat perhatian. 
Penelitian ini berangkat dari teori pola reduplikasi bahasa-bahasa Austronesia oleh Blust (2013) yang disebut memiliki 16 pola reduplikasi. Pola tersebut antara lain reduplikasi penuh (full reduplication), reduplikasi penuh berafiks (full reduplication plus affixation), reduplikasi penuh minus koda (full reduplication minus the coda), reduplikasi penuh minus vokal posisi akhir (full reduplication minus the last vowel), reduplikasi penuh dengan perubahan vokal atau konsonan, atau keduanya (full reduplication with vocalic or consonantal change, or both), reduplikasi penuh dengan empat silabel identik berurutan (full reduplication with four consecutive identical syllables), reduplikasi suku prefiks/reduplikasi ke arah kiri (prefixal foot reduplication/leftward reduplication), reduplikasi suku sufiks/reduplikasi ke arah kanan (suffixal foot reduplication/rightward reduplication), reduplikasi bentuk KVK (CVC-reduplication), reduplikasi bentuk KV ( $\mathrm{CV}$ reduplication), reduplikasi bentuk $\mathrm{KV}$ berafiks ( $\mathrm{CV}$-reduplication plus affixation), reduplikasi bentuk Ka- (Ca-reduplication), ekstensi dari segmen tetap (extensions of fixed segmentism), reduplikasi bersifat infiks (reduplicative infixes), reduplikasi silabel sufiks (suffixal syllable reduplication), dan reduplikasi pola lain (other patterns of reduplication). Keenam belas pola reduplikasi tersebut akan dibandingkan dengan pola reduplikasi yang ada pada bahasa Bali.

\section{TEORI DAN METODOLOGI}

Penelitian ini dilaksanakan dalam tiga tahapan yaitu penyajian data, analisis data, dan penyajian data. Tahap penyajian data dilaksanakan dengan menerapkan metode cakap menggunakan teknik pancing, rekam, dan catat (Sudaryanto, 1993:137-139). Data diperoleh dari para informan, dan beberapa penelitian serta pustaka bahasa Bali dan bahasa-bahasa Austronesia. Analisis data dilaksanakan dengan mengaplikasikan metode komparatif yaitu dengan membandingkan pola reduplikasi pada bahasa-bahasa Austronesia dengan pola reduplikasi pada bahasa Bali. Data disajikan melalui cara formal dan informal, serta kombinasi keduanya (Sudaryanto, 1993:145-157). Penyajian data secara formal dijalankan dengan menggunakan beberapa penanda seperti: tanda penghubung (hypen) untuk batas tiap morfem; tanda titik (period) sebagai penanda batas silabel, unsur reduplikasinya ditebalkan (bold); dan kata dasar (base) masing-masing pola reduplikasi diposisikan di dalam tanda kurung lengkung (round brackets), serta tanda asterisk ${ }^{*}$ sebagai penanda tidak gramatikal/berterima (Kridalaksana, 2008:xvi-xvii). Penyajian data secara informal diterapkan dengan merumuskan analisis dengan uraian kata-kata yang terinci dan jelas. Pada tahapan analisis awal dipaparkan beberapa contoh pola reduplikasi dari bahasa-bahasa Austronesia kemudian diikuti oleh analisis reduplikasi yang ditemukan pada bahasa Bali.

\section{HASIL DAN PEMBAHASAN}

Berdasarkan hasil analisis, dari 16 pola reduplikasi dalam bahasa-bahasa Austronesia ditemukan 5 pola reduplikasi bahasa Bali, antara lain: reduplikasi penuh; reduplikasi penuh berafiks; reduplikasi penuh dengan perubahan vokal atau konsonan, atau keduanya; dan reduplikasi bentuk Ka-; serta reduplikasi pola lain (reduplikasi Кә-) yang belum dibahas pada pola reduplikasi bahasa-bahasa Austronesia secara umum. Adapun pembahasan masing-masing pola tersebut dipaparkan sebagai berikut. 


\section{Reduplikasi penuh}

Reduplikasi penuh terbentuk melalui proses penggandaan kata dasarnya secara menyeluruh. Pola ini dalam bahasa-bahasa Austronesia sebenarnya memang tidak digunakan untuk menandai fungsi gramatikal, walaupun reduplikasi parsial mungkin membawa aspek tersebut. Dalam bahasa-bahasa Austronesia, reduplikasi penuh secara fungsi gramatikal menjadi penanda atau memiliki beberapa fungsi dalam tiap kelas kata. (1) Pada reduplikasi nomina, bentuk ini menandai fungsi (1a) diminutif (diminutive), (1b) jamak, dan (1c) kemiripan/peniruan (similitude). (2) Reduplikasi kelas verba menandai tindakan (2a) repetitif dan (2b) penanda tindakan yang tidak direncanakan (verba intransitif). (3) reduplikasi kelas adjektif menandai fungsi (3a) intensitas dan (3b) penanda hal tidak terduga pada kata dasar adjektif lain. Reduplikasi adverbia tidak dijelaskan oleh Blust (2013). Dalam penentuan kata dasar, hal itu dapat ditentukan jika suatu unsur bisa berdiri sendiri dan memperoleh afiksasi nonreduplikasi (nonreduplicative affixation), serta dalam tuturan bentuk tersebut berterima (Blust, 2013:408409). Namun dalam reduplikasi penuh sejatinya mustahil untuk mengidentifikasi kata dasarnya tanpa memperhatikan sebanyak apapun silabel yang melekat pada unsurunsurnya.

Pada bahasa Bali, pola semua kelas kata di atas ditemukan, namun distribusi fungsi masing-masing kelas kata tidak menyeluruh. Ditemukan tiga bentuk reduplikasi penuh, seperti (1b) Reduplikasi nomina penanda bentuk jamak yang memiliki struktur (nomina+nomina=nomina) seperti cənik-cənik 'kecil-kecil' (cənik 'kecil'), tukad-tukad 'sungai-sungai' (tukad 'sungai'), bikul-bikul 'tikus-tikus' (bikul 'tikus'). (2a) Reduplikasi verba penanda bentuk repetitif berstruktur (verba+verba=verba) dengan contoh jamakjamak 'ambil-ambil' (jamak 'ambil'), bəli-bəli 'beli-beli' (bəli 'beli'). (3a) Reduplikasi adjektif penanda intensitas dengan struktur (adjektif+adjektif=adjektif) seperti pada bentuk lantang-lantang 'panjang-panjang' (lantang 'panjang'), duəg-duəg 'pintar-pintar' (duəg 'pintar'), atau salam-salam 'hitam-hitam' (səlam 'hitam'). Terkait produktivitas distribusi kemunculannya, ketiga bentuk reduplikasi tersebut begitu produktif ditemukan pada bahasa Bali.

Fungsi-fungsi lainnya pada bahasa Bali tidak ditemukan, seperti (1a) diminutif, (1c) kemiripan/peniruan, (2b) penanda tindakan yang tidak direncanakan (verba intransitif), (3b) penanda hal tidak terduga pada kata dasar adjektif lain. Jika dibandingkan dengan bahasa-bahasa Austronesia lain, beberapa bahasa tidak memiliki keseluruhan fungsifungsi tersebut, seperti bahasa Melayu/Indonesia yang hanya memiliki 6 dari 7 fungsi di atas (Blust, 2013:419).

Selain contoh ketiga bentuk sebelumnya, terdapat bentuk berikut yang distribusinya tidak begitu produktif. Berdasarkan data, reduplikasi ini merupakan reduplikasi verba yang tidak memiliki morfem dasar. Bentuk itu dikenal sebagai prakategorial (prakategorial+prakategorial=verba), contohnya laib-laib. Untuk membuktikan hal itu, perhatikan kalimat (1) - (5) berikut. 
(1) Gede laib-laib di rurung.

Gede lari-lari di gang

'Gede lari-lari di gang'.

(2) Gede ma-laibibi sanja

Gede ber-lari kemarin sore

'Gede berlarian kemarin sore'.

(3) Kedis-e ento laib-ang meong

Burung-DEF itu PASS-lari kucing

'Burung itu itu dilarikan kucing'.

$\begin{array}{rlll}\text { (4) *Ia } & \text { laib } & \text { tuni } & \text { səməng } \\ \text { 3SG lari } & \text { tadi } & \text { pagi }\end{array}$

'Dia lari tadi pagi'.

\begin{tabular}{lll}
\multicolumn{2}{c}{ (5) *Kedis-e } & anto laib meng. \\
Burung-DEF & itu lari kucing \\
*'Burung $\quad$ itu & lari kucing'.
\end{tabular}

Konstruksi di atas menunjukkan kalimat (1) gramatikal karena kedua unsur bersatu dalam reduplikasi. Kalimat (2) dan (3) juga berterima dengan pemerolehan afiksasi seperti $\{m ə-\}$ dan $\{-e\}$. Tetapi, pada kalimat (4) dan (5) saat kedua kalimat tersebut berdiri sendiri maka bentuk tersebut tidak berterima. Berdasarkan bukti tersebut maka dapat dikatakan bahwa unsur laib merupakan prakategorial. Berikut merupakan contoh-contoh lain bentuk ini kaing-kaing 'bunyi anjing kesakitan', suil-suil 'bersiul-siul', dan sebaginya.

\section{Reduplikasi penuh berafiks}

Pola ini dibentuk melalui proses penambahan afiksasi nonreduplikasi pada kata dasar. Salah satunya dengan acuan prefiks sebagai imbuhannya, ada tiga pola pada kombinasi reduplikasi dan afiksasi nonreduplikasi (Blust, 2013:419), antara lain: 1) prefiks pada bagian pertama reduplikasi (bahasa Melayu memasak-masak 'memasak'); 2) prefiks pada bagian kedua reduplikasi (bahasa Melayu masak-memasak 'keahlian

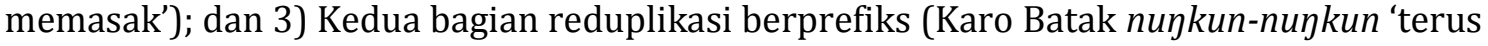
bertanya', kata dasarnya suykun).

Dalam bahasa Bali, ketiga pola tersebut bisa ditemukan pada uraian berikut: pola 1) (sa-+nomina+nomina), dengan contoh sa-dina-dina 'sehari-hari' (dina 'hari'), sa-wai-wai 'sehari-hari' (wai 'hari); (prefiks+verba+verba) ka-sibak-sibak 'dibelah-belah' (sibak 'belah'), ma-paid-paid 'terseret-seret' (paid 'seret'); (sa-+adjektif+adjektif) sa-joh-joh 'sejauh-jauhnya' (joh 'jauh'), sa-lantang-lantang 'sepanjang-panjangnya' (lantang 
'panjang'). Pola 2) hanya ditemukan pada bentuk verba (verba $+\{k a-\}+v e r b a)$ dengan contoh jagur-ka-jagur 'saling pukul' (jagur 'pukul'), paid-ka-paid 'saling tarik' (paid 'tarik'), atau təndang-ka-tandang 'saling tendang' (tondang 'tendang'). Kemudian, pola ke 3) hanya ditemukan pada bentuk verba dan terdapat dalam struktur berikut $(\{m-\}+v e r b a+\{m-$ \}+verba) pada kata mисu-тиси 'saling di pojok' (bucu 'pojok'), maca-maca 'terus membaca' (baca 'baca'). Bentuk-bentuk tersebut begitu produktif ditemukan pada bahasa Bali.

Di sisi lain, pola dengan imbuhan sufiks dalam bahasa-bahasa Austronesia berfungsi sebagai penanda nomina tiruan (simultative noun) dengan pola (nomina+nomina $+\{-a n\}$ ), seperti halnya pada bahasa Melayu anak-anak-an 'boneka' dan Jawa Kuno orang-orang-an 'orang-orangan sawah'. Dalam bahasa Bali pola ini juga terdapat dan distribusinya begitu produktif, misalnya bikul-bikul-an 'sesuatu/mainan menyerupai tikus' (bikul 'tikus'), kadiskadis-an 'sesuatu/mainan menyerupai burung' (kadis 'burung'), celeng-celeng-an 'sesuatu/mainan menyerupai babi (celeng 'babi). Selain itu, pola ini dalam bahasa Bali menandakan fungsi kolektivitas suatu benda, misalnya jukut-jukut-an 'beragam macam sayur' (jukut 'sayur'), woh-woh-an 'beragam macam buah' (woh 'buah'), oong-oong-an 'beragam macam jamur' (oong 'jamur').

Memang dalam buku Blust mengenai reduplikasi dengan penambahan infiks tidak dibahas, akan tetapi bentuk tersebut pastinya terdapat dalam bahasa-bahasa Austronesia, seperti halnya pada bahasa Bali yang distribusinya tidak produktif. Beberapa contohnya yaitu surat-sinurat 'surat-menyurat' (surat 'surat'), raksa-rumaksa 'saling jaga' (raksa 'jaga'), dan sebagainya.

\section{Reduplikasi penuh dengan perubahan vokal atau konsonan, atau keduanya}

Hanya sedikit bahasa-bahasa Austronesia yang mengenal pola ini, namun di bahasa Melayu/Indonesia sangat familiar dengan pola ini. Di bahasa tersebut pola ini dikenal dengan 'reduplikasi imitatif' (Macdonald \& Soenjono, 1967:53). Contoh seperti bolak-balik 'berbaring ke sana kemari' (= bolak 'salah, keliru, tidak kena' + balik 'balik'), jongkatjangkit 'bergerak naik turun' (jongkit 'jongkit'), umbang-ambing 'terumbang-ambing' (umbang 'terumbang), pəcah-balah 'pecah-belah' (= pəcah 'pecah' + bəlah 'belah'), dan sebagainya. Bahasa Melayu/Indonesia memiliki kaidah beragam untuk pembentukan pola reduplikasi ini. Satu hal yang perlu diperhatikan pada pola ini yaitu unsur reduplikasi memiliki kemiripan seperti kata majemuk. Pada reduplikasi pəcah-bəlah 'pecah-belah', keduanya merupakan kata-kata yang bisa berdiri sendiri, sehingga hal ini juga berhubungan dengan kata majemuk. Bila dibandingkan dengan contoh lain, seperti umbang-ambing yang memiliki perbedaan. Unsur umbang bisa berdiri sediri, berbeda dengan unsur pengulangannya ambing yang tidak bisa berdiri sendiri. Menurut Blust (2013:421-422), secara diakronis bentuk pacah-bəlah memang sudah terbentuk dari dahulu di mana bentuk tersebut muncul karena kedua kata memiliki makna yang hampir mirip dan hanya berbeda satu fonem sehingga dimasukkan pada pola ini.

Pada pola ini, bahasa Bali hanya mengalami proses reduplikasi dalam bentuk perubahan vokal. Jika dilihat dari kata dasarnya, perubahan tersebut nampak jelas karena salah satu vokal atau lebih dari unsur pengulangnya mengalami perubahan menjadi vokal $/ a /$, salah satu contohnya dangak-dəngok 'tengak-tengok' (dəngok 'tengok'). Untuk membuktikan kata dasar perulangan ini dapat diperhatikan kalimat (6) - (10) berikut. 
(6) Dangak-dangokgen di jalan-e

Tengak-tengoksaja di jalan-DEF

'Tengak-tengok saja di jalan'!

(7) *Dongak gen di jalan-e

Tengak saja di jalan-DEF

*‘Tengak saja di jalan’!

(8) Dangok gen di jalan-e

Tengoksaja di jalan-DEF

'Tengok saja di jalan'!

(9) *Dangak-in adi-n-ne jumah

Tengak-in adik-GEN-POS di rumah

*'Tengakin adiknya di rumah'!

(10) Dangok-in adi-n-ne jumah

Tengok-in adik-GEN-POS di rumah

'Tengokin adiknya di rumah'!

Dalam tuturan, kalimat (6) tersebut berbentuk gramatikal saat disertai kata dasarnya. Demikian pula pada kalimat (8) dan (10) di mana unsur dəngok dapat berdiri sendiri dengan atau tanpa afiksasi. Sedangkan, kalimat (7) dan (9) yang dilekati unsur dəngak tersebut tidak gramatikal dengan atau tanpa afiksasi. Dapat disimpulkan bahwa unsur dəngok pada reduplikasi merupakan kata dasarnya. Berikut beberapa contoh lain reduplikasi pola ini: kitak-kituk 'menggeleng-geleng' (kituk 'menggeleng'), tundak-tundik 'saling mendorong' (tundik 'dorong'), sladat-sladet 'lirak-lirik' (sladet) 'lirik'), kramakkrimik 'mengumpat' (krimik 'umpat'), krapat-kripit 'berisik' (kripit 'berisik'), sarandangsarendeng 'sempoyongan' (sarendeng 'sempoyong'). Bentuk pola seperti ini dalam bahasa Bali hanya ditemukan pada kelas kata verba dan dengan distribusi terbatas.

\section{Reduplikasi bentuk Ka-}

Reduplikasi Ka- terbentuk melalui proses pengulangan silabel inisial pada kata dasar lalu mengubah nukleusnya menjadi vokal / $a$ /, seperti pada bahasa Dayak Ngaju hahai 'lumayan luas' (hai 'luas'). Untuk kata dasar yang silabel inisialnya hanya berupa satu fonem, vokal tetap / $a$ / ini menjadi reduplikasinya, seperti bahasa Thao a-iup 'semacam tabung yang digunakan untuk meniup api' (m-iup 'meniup sesuatu'). Jika pada kata dasar yang memuat silabel inisial tertutup, maka yang di reduplikasi hanya unsur onset dan nukleus, misalnya pada bahasa Thao ta-tusha 'dua' (tusha 'dua (insani)'). Pola Kaditemukan dalam beberapa bahasa-bahasa Formosa, Chamoro, Bali, dan berbagai daerah di Indonesia Timur, serta beberapa di wilayah Oseania (Blust, 1998). Reduplikasi $\mathrm{Ka}$ - 
dalam rumpun bahasa Austronesia paling tidak memiliki dua fungsi: 1) penanda turunan dalam numeralia (insani) *a-esa 'satu', *da-duSa 'dua', *ta-telu 'tiga', dan seterusnya, dan 2) membentuk nomina deverbal.

Dalam bahasa Bali, fungsi 1) pada numeralia hanya berlaku pada kata da-dua 'dua' (dua 'dua (insani)'), pa-pat 'empat'. Numeralia lainnya tidak bisa berproses dengan pola ini *sa-sa 'satu' (sa 'satu'), *sa-sia 'sembilan (sia 'sembilan'), *da-dasa (dasa 'sepuluh'), dan sebagainya. Fungsi 2) membentuk nomina deverbal dengan distribusinya yang produktif seperti $\boldsymbol{k a}$-kili 'semacam lidi pembersih telinga' (ngili 'membersihkan kotoran telinga'), ba-bisik-an 'bisikan' (bisik 'berbisik'), dan sebagainya.

Pada beberapa bahasa-bahasa Austronesia, ditemukan kata-kata yang setelah berproses dengan reduplikasi $\mathrm{Ka}$ - mengalami fosilisasi seperti yang ditemukan pada bahasa Amis yang kebanyakan kata-katanya pada ranah fauna cacido? 'capung', dadipis 'kecoak', atau kakonah 'semut' (Blust, 1999). Pada bahasa-bahasa Tanimbar-Kei, bentuk reduplikasi yang memfosil juga ditemukan dan lebih mengacu pada kata-kata warna seperti babul 'merah', tatom 'kuning', atau babir 'hijau' (Blust, 2001:27). Bentuk reduplikasi yang mengalami fosilisasi pada kata-kata fauna seperti bahasa Amis tersebut juga terdapat dalam bahasa Bali namun jumlahnya tidak produktif, seperti kakawa 'labalaba', kakua 'kura-kura', atau lalipi 'ular'.

Pada pola ini terdapat satu pola variasi yaitu Reduplikasi KaK- (reduplication CaC-) yang digagas oleh Bowden (2001). Pola ini ditemukan pada bahasa Taba di Halmahera bagian selatan. Pembentukannya melalui proses pengulangan penuh silabel inisial tertutup lalu mengganti vokalnya dengan /a/, seperti tak-tek 'gayung air' (tek 'menggayung air'), law-lewit 'membawa sesuatu dengan galah' (lewit 'membawa sesuatu dengan galah'). Di kasus lain, terdapat proses asimilasi pada koda yang unsur pengulangannya mengikuti onset, misalnya pap-pit 'jebakan dari tali' (pit 'menangkap menggunakan jebakan dari tali'). Sayangnya, di bahasa Bali tidak ditemukan data yang menunjukkan pola variasi tersebut.

\section{Reduplikasi pola lain (Reduplikasi Kə-)}

Berikut ini merupakan satu pola unik pada bahasa Bali yang belum dibahas pada pola reduplikasi rumpun bahasa Austronesia. Jika diperhatikan secara saksama, pola ini masih memiliki kemiripan dengan Reduplikasi $\mathrm{Ka}$ - berikut prosesnya, namun perbedaan signifikannya adalah vokal perubahannya bukanlah $/ a$ / melainkan / $/$ /. Jika memang pola ini seharusnya termasuk ke dalam Reduplikasi $\mathrm{Ka}$-, akan tetapi bahasa Bali telah memiliki kata-kata berpola seperti itu. Bahasa Bali memang memiliki kecenderungan untuk membunyikan fonem /a/ menjadi bunyi /ə/, tetapi bunyi tersebut hanya muncul pada akhir kata silabel terbuka, misalnya mata /matə/ 'mata', pata /patə/ 'omong', atau bapa /bapə/ 'bapak'.

Pola reduplikasi Kə- hanya ditemukan pada kelas kata nomina. Fungsi pola ini adalah untuk menandai bentuk kolektivitas dan tanpa mengubah bentuk dasarnya pada kelas kata nomina. Data tentang reduplikasi ini tidak terlalu produktif ditemukan pada bahasa Bali. Beberapa contoh dari bentuk ini seperti so-sate 'sate' (sate 'sate'), bə-banten 'kelengkapan upacara' (banton 'kelengkapan upacara'), so-sari 'uang' (sari 'uang'), atau pepineh 'pemikiran' (pineh 'pikiran'). Bentuk-bentuk tersebut misalnya sate dan sa-sate kadang-kadang memiliki fungsi sama sebagai penanda tunggal dan jamak. Lebih lanjut, ada kemungkinan pola unik ini termasuk ke dalam salah satu bentuk variasi pola Reduplikasi Ka-, seperti pada pola Reduplikasi KaK-. Tetapi bentuk itu hanya menambah konsonan pada koda, dan juga terjadi proses asimilasi koda mengikuti onset pada unsur 
pengulangannya. Sehingga, hal ini pun memperkuat asumsi bahwa pola baru ini merupakan bagian dari pola lain dari reduplikasi bahasa-bahasa Austronesia yang belum dibahas.

\section{SIMPULAN}

Berdasarkan pemaparan hasil dan pembahasan, dapat disimpulkan bahwa bahasa Bali memiliki 4 pola dari 16 pola umum yang ada pada bahasa-bahasa Austronesia, yaitu: (1) reduplikasi penuh, (2) reduplikasi penuh berafiks, (3) reduplikasi penuh dengan perubahan vokal atau konsonan, atau keduanya, dan (4) reduplikasi bentuk Ka-. Di sisi lain, ditemukan satu pola baru pada bahasa Bali yang belum dipaparkan dalam bahasabahasa Austronesia yaitu reduplikasi Кə-.

Beberapa pola temuan di atas memang jika dianalisis secara deskriptif memiliki hasil yang berbeda pada hasil penelitian lain. Namun khusus pada penelitian ini yang menggunakan ancangan komparatif berdasarkan pola reduplikasi bahasa-bahasa Austronesia pada umumnya maka analisis ini pun mengikuti model yang ada pada bahasabahasa Austronesia, khususnya pada buku Blust (2013). Memang bisa dikatakan bahwa hasil ini belum bisa dikatakan sebagai pola mutlak yang ada pada bahasa Bali, akan tetapi penemuan ini diharapkan bisa menemukan menjadi ancangan awal dalam menganalisis secara komparatif pola reduplikasi berdasarkan pola pada bahasa-bahasa serumpun. Secara khusus, penemuan pola reduplikasi Кә- ini diharapkan mampu menambah dan berdampak signifikan pada kekayaan pola reduplikasi bahasa-bahasa Austronesia.

\section{DAFTAR PUSTAKA}

Bawa, I W., \& Jendra, I W. (1981). Struktur bahasa Bali. Jakarta: Pusat Pembinaan dan Pengembangan Bahasa.

Bowden, J. (2001). Taba: description of a South Halmahera language. Canberra: Pacific Linguistics.

Blust, R. (1998). Ca- reduplication and Proto-Austronesian grammar. Oceanic Linguistics, 3(7), 29-64.

Blust, R. (2001). Reduplicated colour terms in Oceanic languages. Dalam Pawley, A. K., Ross, M., \& Tryon, D. (Eds.), The Boy From Bundaberg: Studies in Melanesian Linguistics in Honour of Tom Dutton (hlm. 23-49). Canberra, Australia: Pacific Linguistics.

Blust, R. (2013). The Austronesian languages (revised edition). Canberra: Asia-Pacific Linguistics.

Due, A. (2016). Reduplikasi bahasa Kambowa. Jurnal Humanika, 1(16). Diambil dari http://ojs.uho.ac.id/index.php/HUMANIKA/article/view/747/pdf, pada 17 Desember 2017.

Hilsam. (2016). Reduplikasi bahasa Tolaki. Jurnal Humanika, 1(16). Diambil dari http://ojs.uho.ac.id/index.php/HUMANIKA/article/view/744/pdf, pada 17 Desember 2017.

Matthews, P. H. (1978). Morphology: an introduction to the theory of word structure. Cambridge: Cambridge University Press.

Macdonald, R. R., \& Soenjono, D. (1967). A student's reference grammar of modern formal Indonesian. Washington, DC.: Georgetown University Press. 
Miles, M. B., \& Huberman, A. M. (1994). Qualitative data analysis. London: Sage Publications.

Ramlan, M. (2012). Morfologi: suatu tinjauan deskriptif. Yogyakarta: Karyono.

Rizal, F. (2016). Sistem reduplikasi bahasa Muna (suatu kajian transformasi generatif). Jurnal Humanika, 1(16), 1-15. Diambil dari http://ojs.uho.ac.id/index.php/HUMANIKA/article/view/743/pdf, pada 16 Desember 2017.

Samsuri. (1982). Analisa bahasa. Jakarta: Erlangga.

Sudaryanto. (1993). Metode dan aneka teknik analisis bahasa: pengantar penelitian wahana kebudayaan secara linguistis. Yogyakarta: Duta Wacana University Press.

Verhaar, J. W. M. (2008). Asas-asas linguistik umum. Yogyakarta: Gadjah Mada University Press. 